\title{
The Biography of Faxian: On the Practice and Spread of Chinese Buddhist Precepts during the Jin and Song Dynasties (Fourth-Fifth Century CE)
}

ZHANG XUESONG 張雪松

Institute for the Study of Buddhism and Religious Theory, Renmin University of China

32431462@qq.com

English Translation by Gina Yang, forial1999@gmail.com

Keywords: Faxian, novice, śrāmanera, precepts, Mobe sengqi lü, Mahāsānghika Vinaya, Shisong lü, Daśabhānavāra Vinaya, Xin Monastery

DOI: https://dx.doi.org/10.15239/hijbs.02.01.11

Abstract: This paper discusses the religious importance of Faxian receiving the novice (śramanera) precepts early in life, his travel to the West in search of Dharma as an adult, his engagement in translating Buddhist scriptures after returning to China, and his relocation to Xin Monastery in later life. The focus of discussion is the significance of Faxian's search, translation and propagation of Buddhist precepts during his lifetime. Furthermore, the current paper points out potential fallacies of some common claims about Faxian's biography. From this, it investigates the practice and spread of Chinese Buddhist precepts during the Jin and Song dynasties. 


\title{
Receiving Novice Precepts Regarded as a Means of Preventing Premature Death for Young Children from the Fourth Century Onwards
}

\begin{abstract}
$\Lambda$ pproximately in the first half of the fourth century, the religious - custom of adopting out young children to Buddhist monasteries can be seen in northern China. For instance, 'Fotucheng zhuan' 佛圖澄傳 (The Biography of Fotucheng) in Gaoseng zhuan 高僧傳 (The Biographies of Eminent Monks), has:
\end{abstract}

Shi Hu had a son named [Shi] Bin. Later, he was much loved by [Shi] Le, but suddenly died of illness. After two days had passed, [Shi] Le said, 'I have heard that the prince of Guo is dead. The [doctor] Bian Que is able to give life. Great master, spiritual leader of the nation, you should quickly go and inform him, as he will certainly be able to bring blessings'. Fotucheng then took a willow wand and recited a mantra. In an instant [Shi Bin] was able to rise, and soon returned to health. Due to this, [Shi] Le often raised his young sons in Buddhist monasteries. Every [year] on the eighth day of the fourth month, [Shi] Le would personally go to the monastery to bathe the Buddha's statue, and make vows on behalf of his sons.

石虎有子名斌, 後勒愛之甚重, 忽暴病而亡. 已涉二日, 勒日： ‘朕 聞虢太子死, 扁鵲能生. 大和上, 國之神人, 可急往告, 必能致福.' 澄乃取楊枝咒之, 須四能起, 有頃平復. 由是勒諸稚子, 多在佛寺 中養之. 每至四月八日, 勒躬自詣寺灌佛, 為兒發願. ${ }^{1}$

'Fotucheng zhuan' in Jin shu 晉書 (The Book of Jin) also records the same account in a slightly more concise manner:

[Shi] Le's beloved son [Shi] Bin suddenly died of illness. As he was about to be placed into the coffin, [Shi] Le exclaimed, 'I have heard that the prince of Guo has died. [The doctor] Bian Que would be

1 Tang, Gaoseng zhuan, 348. 
able to give him life. Can that be made to happen now'? He then ordered Fotucheng, who then took a willow wand, dipped it in water, and sprinkled the water while reciting mantras. Taking [Shi] Bin's hand, he said, 'May you arise'! Due to this, he recovered and soon returned to health. From this, many of [Shi] Le's sons were raised in Fotucheng's monastery.

勒愛子斌暴病死, 將殯, 勒靯日: ‘朕聞虢太子死, 扁鵲能生之, 今可 得效乎?’乃令告澄. 澄取楊枝沾水, 灑而咒之. 就執斌手日: ‘可起 矣!’ 因此遂蘇, 有頃, 平復. 自是勒諸子多在澄寺中養之. ${ }^{2}$

There are clear historical records showing that Shi Bin 石斌 was Shi Hu's 石虎 son, and that he died in 349 CE. The section on 'Fotucheng zhuan' in Jin sbu that states that Shi Bin was Shi Le's 石勒 beloved son is in fact erroneous. Hence, we should adopt the record of 'Shi Hu has a son called [Shi] Bin' 石虎有子名斌, from 'Fotucheng zhuan' in Gaoseng zhuan.

The relationship between Shi Le and Shi Hu was complex:

Shi Le's 石勒 courtesy name was Shi Long 世龍... his father was Zhou Hezhu 周曷朱. ... Shi Jilong 石季龍 (Shi Hu 石虎), was [Shi] Le's nephew. ... [Shi] Le's father, [He]zhu, took Jilong as his son when he was a young child. Because of this, [Shi $\mathrm{Hu}]$ was sometimes called [Shi] Le's younger brother.

石勒字世龍......父周曷朱. ......石季龍 (石虎), 勒之從子也. ...... 勒父朱幼而子季龍, 故或稱勒弟焉. ${ }^{3}$

Shi Le was twenty-one years older than Shi Hu. If Shi Hu was Shi Le's nephew, then their relationship was as uncle and nephew. This would mean that Shi Bin was Shi Le's beloved grandson. However, according to records in Jin shu, when Shi Hu was young, he was adopted by Shi Le's father, Zhou Hezhu. Hence, Shi Hu was Shi Le's younger broth-

2 Jin shu 282.2487.

3 Jin shu 282.2707, 2761. 
er. Moreover, Shi Le and Shi Hu were also called Shi Shilong and Shi Jilong respectively, which clearly indicated that they were brothers. Shi $\mathrm{Hu}$ was called Ji[long], which indicates that he was the youngest (bo 伯, meng 孟, zhong 仲, shu 叔 and $j i$ 季 [the eldest, second, third, fourth, and youngest of brothers]). Zizhi tongjian 資治通鑒 (Comprehensive Mirror in Aid of Governance) reports the following:

From a young age, the Jie man Shi Le from Wuxiang in Shangdang Prefecture had strength and courage, and was skilled in horse riding and archery. During a great famine in Bingzhou, the Jianwei General Yancui told the Duke of Dongying, Teng, to take the Hu barbarians to Shandong, and there to sell them for military purposes. [Shi] Le was also captured at the time, and sold as a slave to Shi Huan of Chiping. Impressed by [Shi Le's] strong physical appearance, Huan freed him. Huan's home was near to a horse ranch, and there [Shi] Le, together with the ranch leader Ji Sang, formed a group of strong men into a gang of bandits. With the rise of Gong Shifan, [Ji] Sang and [Shi] Le commanded several hundred horsemen and went to aid him. [Ji] Sang was the first to give [Shi] Le the family name Shi and given name Le.

初, 上党武鄉羯人石勒, 有膽力, 善騎射. 並州大饑, 建威將軍閻粹 說東嬴公騰執諸胡於山東, 賣充軍實. 勒亦被掠, 賣為花平人師懽 奴, 懽奇其狀貌而免之. 懽家鄰於馬牧, 勒乃與牧帥汲桑結壯士為 群盗. 及公師籓起, 桑與勒帥數百騎赴之. 桑始命勒以石為姓, 勒 為名. ${ }^{4}$

We can see from here that Shi Le adopted Shi 石 as his family name after he was captured, then sold to and freed by Shi Huan 師 懽, and later became a bandit. The names of Shi Shilong and Shi Jilong appeared around or after this time. Furthermore, according to 'Records on Shi Le' in Jin shu, Shi Le was captured 'when [he was] over twenty years old' (時年二十餘). ${ }^{5}$ This was the time when Shi Hu

4 Zizbi tongjian 86.2709-10.

5 Jin shu 104.2708. 
was born. Hence, when Shi Hu was young, Shi Le was captured and they were separated. It is especially worth noting that, as a youth, Shi Hu was living with Shi Le's mother. 'Records on Shi Jilong' in Jin shu state:

During the Yongxing period, [Shi Hu] was separated from [Shi] Le. Later, Liu Kun sent [Shi] Le's mother, [Lady] Wang, and Jilong to Gepi. At the time he was seventeen.

永興中, 與勒相失. 後劉琨送勒母王及季龍於葛陂, 時年十七矣. ${ }^{6}$

At the time, Shi Le planned to kill Shi Hu, but Shi Le's mother protected him: 'When the work ox was a calf, he often broke the cart. You should tolerate him' (快牛為犢子時, 多能破車, 汝當小忍 之) ${ }^{7}$

From the above indications, we might speculate that Shi Le's father, Zhou Hezhu, passed away when he was an adult. His mother might have remarried Shi Hu’s father, [Shi] Koumi 寇䚇. Therefore, under this situation, Shi Le and Shi Hu were half-brothers, (instead of [Shi] Le's father, [He]zhu, who took Jilong as his son when he was young). In this way, when Shi Le passed away, Shi Hu deposed Crown Prince Shi Hong, who was appointed by Shi Le, and took over the throne, then it was a case of agnatic seniority. Imperial succession during the Sixteen Kingdoms and Northern Dynasties period was fought over extremely aggressively, whether the system was by agnatic primogeniture or agnatic seniority. In addition, the cover up of the 'disgrace' of empress dowagers' remarriages in the history books by later generations made the relationships among many brothers murky and unclear. The half-brother relationship between Shi Le and Shi Hu might have been covered up due to the factors above. Many similar cases might have existed during that period of time in history. For instance, in Professor Li Ping's 李憑 research on the coup d'état of the Prince of Qinhe 清河 of the Northern Wei,

6 Jin shu 106.2761.

7 Jin shu 106.2761. 
it was found that Tuoba Lie 拓咙烈 and Emperor Daowu 道武 were half-brothers with the same mother. ${ }^{8}$

Records from the Jin shu concerning this part of history changed Shi Hu to Shi Le. By doing so, it not only covers up the half-brother relationship between Shi Le and Shi $\mathrm{Hu}$, but also creates the severe error of assigning Shi Bin as the son of Shi Le. If Shi Le and Shi Hu were brothers, then Shi Hu's son, Shi Bin, would be of the same generation as the 'young sons' of Shi Le. In other words, they would be brothers. Hence, records in Gaoseng zhuan concerning accounts of Shi Bin being cured by Fotucheng, '[Shi] Le's young sons' being sent to be raised in the monastery, are reasonable. It also confirms that Shi Le and Shi Hu were brothers, as well as providing circumstantial evidence for the historical fact of Shi Le's mother remarrying Shi Hu's father.

According to Faxian's biography in the Gaoseng zhuan:

Shi Faxian, lay family name Gong, was from Wuyang in Pingyang. He had three older brothers, who all died at a young age. The father feared that the same misfortune would also happen to Faxian, and so at the age of three, he was tonsured as a novice monk. Living at home for a few years he fell ill and was near death. He was therefore sent back to the monastery, where by living in faith he was cured. He was not willing to return home, and although his mother wished to see him, she was unable to do so. A small hut was built outside the [monastery] gate to facilitate coming and going. At the age of ten, his father passed away, and since his mother was a widow without support, his paternal uncle forced him to return to lay life. Faxian said, 'Originally, it is not because I have a father that I renounced my home. It is because I wished to be far from the dust of the world and away from secular life that I entered the way'. His uncle approved of what he said, and so desisted. Not long after, his mother also passed away. His sentiment surpassed others. After the funeral was over, he returned to the monastery.

$8 \quad \mathrm{Li}$, Beiwei pingcheng shidai, 98-112. 
釋法顯, 姓龔, 平陽武陽人. 有三兄, 並髺龆而亡. 父恐禍及顯, 三 歲便度為沙爾. 居家數年, 病篤欲死, 因以送還寺, 信宿, 便差. 不 肯復歸, 其母欲見之不能得, 後為立小屋於門外, 以擬去來. 十歲 遭父憂, 叔父以其母寡獨不立, 逼使還俗, 顯日：“本不以有父而出 家也，正欲遠塵離俗，故入道耳．”叔父善其言，乃止. 頃之，母喪. 至性過人. 葬事畢, 仍即還寺. 9

Records in Sengyou's 僧祐 (445-518) Chu sanzang ji ji 出三藏記 集 [Compilation of Documents on the Translation of the Tripitaka] are similar to the passage found in the commonly circulated edition of Gaoseng zhuan:

Shi Faxian, lay family name Gong, was from Wuyang in Pingyang. Faxian had three older brothers, who all died at a young age. The father feared that the same misfortune would also happen to him, and so at the age of three he was tonsured as a novice monk. Living at home for a few years, he fell ill and was near death. Therefore, he was sent back to the monastery, where by living in faith he was cured. He was not willing to return home, and although his mother wished to see him she was unable to do so. A small hut was built outside the [monastery] gate to facilitate coming and going. At the age of ten, his father passed away, and since his mother was a widow without support, his paternal uncle forced him to return to lay life. Faxian said, 'Originally, it is not because I have a father that I renounced my home. It is because I wished to be far from the dust of the world and away from secular life that I entered the way'. His uncle approved of what he said, and so desisted. Not long after, his mother also passed away. His sentiment surpassed others. After the funeral was over he then returned to the monastery.

釋法顯, 本姓龔, 平陽武陽人. 顯有三兄, 並髺噛而亡. 其父恐禍及 之, 三歲便度為沙爾. 居家數年, 病篤欲死, 因送還寺, 信宿便差. 不肯復歸, 母欲見之不能得, 為立小屋於門外, 以擬去來. 十歲遭 父憂, 叔父以其母寡獨不立, 逼使還俗. 顯日: ‘本不以有父而出家

\footnotetext{
$9 \quad$ Tang, Gaoseng zhuan, 87.
} 
也. 正欲遠塵離俗，故入道耳．＼cjkstart叔父善其言，乃止. 頃之母喪，至 性過人. 葬事既畢, 仍即還寺. ${ }^{10}$

The phrase 'his sentiment surpassed others' comes from Ji Kang's Yu Shan Juyuan juejiao shu 與山巨源絕交書 [Letter of Breaking off Relations with Shan Juyuan]: 'His sentiment surpassed others, he did not harm anything' (至性過人, 與物無傷). This describes a person's pure and honest nature. In the Faxian zhuan, there should have originally been other phrases before or after the statement, 'His sentiment surpassed others', to have a coherent meaning. This particular section from Gaoseng zhuan (including passages that are incoherent) would have been taken from the relevant section in $\mathrm{Chu}$ sanzang jiji.

After Fotucheng cured Shi Bin, Shi Bin's uncle, Shi Le, sent his sons to be raised in the monastery. Following the death of Faxian's three older brothers at a young age, his father sent Faxian to the monastery to receive the novice precepts. These cases demonstrate that the religious custom of sending young children to monasteries to be tonsured as novices in order to prevent death at a young age already emerged in northern China during the fourth century. The children of the Shi family during the late Zhao regime who were sent to be raised in the monasteries might have been tonsured as novices as well.

Fotucheng's biography in the Gaoseng zhuan reports:

At the time, Crown Prince Shi Sui had two sons in the Kingdom of Xiang. Fotucheng said to [Shi] Sui, 'Little A-mi will become ill. You should take him back'. [Shi] Sui then hurriedly sent out a messenger to see him, and he was already ill. The great physician, Yin Teng, and foreign Buddhists all said that they would be able to cure him. Fotucheng told his disciple Faya, 'Even if the holy man comes back, he could not heal this disease, let alone men like these!' Three days later [the son] died.

10 Su and Xiao, Chu sanzang ji ji, 573. 
時太子石遂有二子在襄國，澄語遂日：“小阿彌比當得疾，可往迎 之.’遂即馳信往視, 果已得病. 大醫殷騰及外國道士自言能治, 澄 告弟子法雅日：‘正使聖人復出，不愈此病,況此等乎!’ 後三日果 死. ${ }^{11}$

Fotucheng's biography in the Jin shu also contains this record. The only discrepancy is Fotucheng's disciple, Zhu Faya 竺法雅, was mistaken as 'Faya' 法牙:

Jilong Crown Prince [Shi] Sui had two sons in the Kingdom of Xiang. Fotucheng said to [Shi] Sui, 'Little A-mi will become ill. You should take him back.' [Shi] Sui then raced to send out a messenger to see him, but he was already ill. The great physician Yin Teng and the foreign Buddhist monks all said that they would be able to heal him. Fotucheng told his disciple Faya, 'Even if the holy man comes back, he could not heal this disease, let alone men like these!' Three days later [the son] died.

季龍太子遂有二子, 在襄國, 澄語遥日: ‘小阿爾比當得疾, 可往看 之.’ 遂即馳信往視, 果已得疾. 太醫殷騰及外國道士自言能療之, 澄告弟子法牙日: ‘正使聖人復出, 不愈此疾, 況此等乎! 後三日 果死. ${ }^{12}$

Shi Sui's youngest son was called 'little Ami'. 'Ami' 阿彌 might have been his name, just as Wang Min 王嘪 of the Eastern Jin period was called 'little Ami' in his youth. The Biography of Sanghadeva (Sengqietipo 僧伽提婆) in the Gaoseng zhuan has:

Sanghadeva then arrived, and [Wang] Xun immediately extended an invitation. Thereupon, he lectured on the Abbidharma in his house, and renowned monastics all gathered. Sanghadeva's essential points were most refined, and the sense of his words was clear and defined. When putting forth the principles, the assembly were all enraptured.

\footnotetext{
11 Tang, Gaoseng zhuan, 349.

12 Jin shu 95.2488.
} 
At the time, Wang and Mi were also seated there listening, and [Mi] later lectured it elsewhere. [Wang] Xun asked the Buddhist monk Fagang, 'What has A-mi learned?' He answered, 'The overall essentials are all correct. The minor points have not yet been examined in detail'.

提婆既至, 珣即延請. 仍於其舍講《阿毗曼》, 名僧畢集. 提婆宗致 既精, 詞旨明析, 振發義理, 眾咸悅悟. 時王彌亦在座聽, 後於別屋 自講，珣問法綱道人: ‘阿彌所得云何?’ 答日: ‘大略全是，小未精 覈耳.' ${ }^{13}$

Slight differences can be seen in Sanghadeva's biography in the Chu sanzang ji ji:

Sanghadeva then arrived, and [Wang] Xun immediately extended an invitation. Thereupon, he lectured on the Abhidharma in his house, and renowned monastics all gathered. Sanghadeva's essential points were most refined, and the sense of his words was clear and defined. When putting forth the principles, the assembly were all enraptured. At the time, Wang Xun and Sengmi were also seated there listening, and [Sengmi] later lectured it elsewhere. [Wang] Xun asked the Buddhist monk Fagang, 'What has Sengmi learned?' He answered, 'The overall essentials are all correct. The minor points have not yet been examined in detail'.

提婆至止, 珣即延請. 仍於其舍講《阿毗曼》, 名僧畢集, 提婆宗致 既精, 辭旨明析, 振發義奧, 眾咸悅悟. 時王珣、僧彌亦在聽坐, 後 於別屋自講. 珣問法綱道人: ‘僧爾所得云何?’ 答日: ‘大略全是, 小未精核耳.' ${ }^{14}$

Wang Xun's 王珣 younger brother, Wang Min 王琘, had the childhood name of Sengmi 僧彌. The Gaoseng zhuan mistook it as Ami 阿彌. Wang Min's biography in the Jin shu has:

13 Tang, Gaoseng zhuan, 38.

$14 \mathrm{Su}$ and Xiao, Chu sanzang ji ji, 525. 
[Wang] Min's courtesy name was Jiyan. From a young age, he was talented in the arts and skilled at calligraphy, such that his renown exceeded that of [Wang] Xun. People at the time commented on this, saying, 'It is not that Fahu is not excellent, but Sengmi poses difficulties for his elder brother'. Sengmi was the childhood name of [Wang] Min. At the time, a foreign śramana named Sanghadeva, who had a subtle understanding of the principles of the Dharma, lectured on the Abbidharma Sutra for Xun's brothers. Although Min was still very young at the time, halfway through the lecture he declared that he already understood it. Just after this, he himself lectured on it to the śramana Fagang and a number of other people elsewhere. Fagang exclaimed, 'The main principles are all correct, just the minor points have yet to be examined'.

琩字季琰. 少有才藝, 善行書, 名出珣右. 時人為之語日：“法護非 不佳, 僧彌難為兄.’ 僧彌, 琘小字也. 時有外國沙門, 名提婆, 妙 解法理, 為珣兄弟講《毗昙經》. 琘時尚幼, 講未半, 便云已解, 即 於別室與沙門法綱等數人自講. 法綱歎日: ‘大義皆是，但小未精 耳.' ${ }^{15}$

Wang Xun's childhood name was 'Fahu' 法護. ${ }^{16}$ His younger brother, Wang Min, had the childhood name Sengmi. Both childhood names seem to have the meaning of seeking protection from the triple gem: the Buddha, Dharma and Sangha. In Sengqietipo's biography in the Gaoseng zhuan, Wang Min was referred to as 'Ami'. Fotucheng's biography in the Gaoseng zhuan records that Shi Sui had two sons, who seemed to be known as elder and younger [little] 'Ami'. However, it is unlikely that both sons shared the same name of 'Ami'. Another explanation is that 'Ami' is actually 'shami' 沙爾 [novice], that is, Shi Sui's two sons were both tonsured as novices to avoid premature death. Despite this, Shi Sui's youngest son was unable to avoid the fate of dying at a young age, even after being tonsured as a novice. Fotucheng said to Zhu Faya, 'Even if the holy man

\footnotetext{
15 Jin shu 65.1758.

16 Jin shu 65.1757.
} 
were to do his work again, he could not heal this disease' (正使聖人 復出, 不愈此病). The 'holy man' 聖人 refers to the Buddha, meaning that even the Buddha could not save him.

Furthermore, it is worth noting that according to Faxian's biography in the Gaoseng zhuan, Faxian was tonsured as a novice at the age of three. However, he did not live at the monastery. He was only sent to stay at the monastery when he became critically ill. Once he got better, a 'small hut' 小屋 was set up outside the monastery 'to facilitate coming and going' 以擬去來. In other words, raising young children in a monastery was not the only way to prevent calamities of illness and death. One could be protected by simply undertaking the religious act of tonsuring and receiving novice precepts. There was no need to live in the monastery. Hence, we can see that by the mid to late fourth century at the latest, in the practice of Buddhism in northern China, receiving the novice precepts was seen as a function to protect children, as being able to prevent their death at a young age. Young children who received the novice precepts for the sake of preventing illness and preserving life did not have to be raised in the monasteries. Furthermore, they did not have to renounce as monastics in the future. Although Faxian received the novice precepts at the age of three, it was only after his recurring illness, the passing of his parents, and at his own insistence that he finally formally renounced as a monastic in his teens.

The Dates of Faxian and the Age at Which He Travelled to the West in Search of the Vinaya

Based on traditional descriptions, Chinese monastics only began farming after the establishment of the Pure Rules, 'a day without work is a day without food' (一日不作, 一日不食), by the Chan patriarch Baizhang 百丈 during the Tang dynasty. When Faxian first renounced, he worked in the fields. Faxian's biography in the Chu sanzang ji ji states:

He tried to go to the fields and harvest the rice paddy with several dozen of his classmates. At the time, there were hungry bandits who 
wanted to steal their grain. All the novices fled, and Faxian alone remained. He said to the bandits, 'If you want the grain, take as much as you need. However, gentlemen, you have not practiced generosity in the past, and so now you are hungry and poor. If you steal from others now, I am afraid that in future lives it will be even worse. I tell you this because a life of poverty has caused you gentlemen much sorrow in the past'. Having said this, he left. The bandits then dropped the grain and left. Everyone in the community of several hundred monastics was greatly impressed.

嘗與同學數十人於田中刈稻，時有饑賊欲奪其穀，諸沙爾悉奔走， 唯顯獨留. 語賊日: ‘若欲須穀, 隨意所取. 但君等昔不佈施, 故此 生饑貧, 今復奪人, 恐來世彌甚. 貧道預為君憂, 故相語耳! ’言訖 即還. 賊棄穀而去. 眾僧數百人, 莫不嘆服. ${ }^{17}$

Records of monastics working in the fields during the Wei, Jin, Northern and Southern dynasties are common. Another example is Dao'an, who also worked in the fields during his early days. Dao'an's biography in the Chu sanzang $j i$ ji says:

He renounced at the age of twelve. He was of spiritual nature, intelligent and sensitive, but his physical appearance was ugly, and so he was not favoured by his teacher. He was put out to work in the fields, and for three years he worked there diligently without any sign of complaint. He was by nature very hard working, and never missed the fasting day precepts. Only after several years did he visit his teacher to seek the sutras. The teacher gave him the Bianyi jing (Skt. Pratibhānamati-pariprcchbā-sūtra), in one juan, with over 5,000 characters. Carrying the sutra, Dao'an went into the fields and read it during a break. Returning at dusk, he gave the sutra back to his teacher, and asked for another sutra. The teacher said, 'You have not even read yesterday's sutra, why do you now ask for more'? [Dao'an] replied, 'I have already read it thoroughly'. Although the teacher was surprised by this, he did not believe it. He

17 Su and Xiao, Chu sanzang ji ji, 573. 
then gave him the Chengju guangming jing, in one juan, with a little less than 10,000 characters. He took it with him as before, and in the evening returned it to the teacher. The teacher took the sutra and tested his [memorization]. He did not miss a single character. The teacher was greatly astonished and honoured him with special favour. Later, he received full ordination and was free to travel to different places.

年十二出家, 神性聰敏, 而形貌至陋, 不為師之所重. 驅使田舍, 至 於三年, 執勤就勞, 曾無怨色. 篤性精進, 齋戒無関, 數歲之後, 方 啟師求經. 師與《辯意經》一卷, 可五千餘言. 安齎經入田, 因息尋 覽. 暮歸, 以經還師, 復求餘經. 師日: ‘昨經不讀, 今復求耶!’ 對 日: ‘即已闇誦.’ 師雖異之, 而未信也. 復與《成具光明經》一卷, 可減萬言, 齎之如初, 暮復還師. 師執經覆之, 不差一字 .師大驚 嗟, 敬而異之. 後為受具戒, 恣其游方. ${ }^{18}$

Dao'an started working in the fields at the age of twelve. He worked for three years before studying the scriptures. When he first began learning the scriptures, he did so among the fields during breaks from farming. However, it is worth noting that Dao'an was working in the fields before receiving full ordination and that Faxian, too, was working in the fields before 'receiving full ordination at twenty' (二十受大戒). This means that in the practice of Vinaya in Chinese Buddhism during the fourth century, novices could work in the fields after receiving novice precepts, whereas monastics could not work in the fields after receiving full ordination, otherwise they would break the precepts.

According to Faxian's biography in the Chu sanzang ji ji:

At the age of twenty, he received full ordination. His determined practice was clear and pure, his ritual demeanour proper and dignified. He often lamented that there was material missing from the sutras and Vinaya, and made determined vows to seek it. In the third year of Longan during the Jin dynasty, [he] set out from Chang'an

$18 \mathrm{Su}$ and Xiao, Chu sanzang ji ji, 561. 
and crossed west over the desert, together with his classmates Huijing, Daozheng, Huiying, Huiwei and others.

二十受大戒, 志行明潔, 儀軌整肅. 常概經律外閶, 誓志尋求. 以晉 隆安三年, 與同學慧景、道整、慧應、慧嵬等發自長安, 西度沙河. ${ }^{19}$

Faxian's biography in the Gaoseng zhuan does not contain the record of 'at the age of twenty':

He received full ordination. His determined practice was clear and sharp, his ritual demeanour proper and dignified. He often lamented that there was material missing from the sutras and Vinaya, and made determined vows to seek for it. In the third year of Longan during the Jin dynasty, [he] set out from Chang'an and crossed west over the desert, together with his classmates Huijing, Daozheng, Huiying, Huiwei and others.

及受大戒, 志行明敏, 儀軌整肅. 常概經律外関, 誓志尋求. 以晉隆 安三年, 與同學慧景、道整、慧應、慧嵬等, 發自長安, 西渡流沙。 ${ }^{20}$

The Faxian zbuan 法顯傳 [Account by Faxian], that is, the Foguo $j i$ 佛國記 [The Record of Buddhist Countries], states:

In the past, Faxian was in Chang'an and lamented that there was missing material from the Vinaya canon. Therefore, in the first year of Hongshi, at the end of the year during the Jihai phase, he went to India seeking the Vinaya with his companions Huijing, Daozheng, Huiying, Huiwei and others.

法顯昔在長安, 慨律藏殘缺, 於是遂以弘始元年, 歲在己亥, 與慧 景、道整、慧應、慧嵬等同契, 至天答尋求戒律. ${ }^{21}$

19 Su and Xiao, Chu sanzang ji ji, 573-74.

20 Tang, Gaoseng zhuan, 87-88.

21 Zhang, Faxian zhuan jiaozbu, 2. 
We are more certain that Faxian began his journey to the West in the third year of Longan (399 CE). However, we are not certain of his age at the time. Chen Yuan 陳垣 states in his Shishi yinian lu 釋氏 疑年錄 [Record of Dubious Dates of Buddhist Monks]:

Faxian, of Xin Monastery in Jiangling, (lay family name Gong, from Wuyang in Pingyang), died before the first year of Jingping in the Song (423 CE). There is no year for his death in his biography, and only the Chu sanzang ji ji, juan 3, 'Preface to the Mishasai lü' (Mahiśsásaka-vinaya), states: 'Faxian returned to the capital in the twelfth year of Yixi, during the Jin. He made many translations of a number of sutras. The translation of only one text, the Mishasai $l \ddot{u}$, was lost (or: he died) before it was completed. In the first year of Jingping, during the Song, it was translated (or: recited) by Buddhajiva'. Fotuoshi's biography in the Liang dynasty monastic biography (i.e. Gaoseng zhuan, juan 3) states the same, i.e. that Faxian died before the first year of Jingping during the Song. Also, Faxian's age is given in the Chu sanzang ji ji (juan 15) as eighty-two years, but Liang dynasty monastic biography (i.e. Gaoseng zhuan, juan 3) has eighty-six. Neither of them provide evidence. The Chu sanzang ji ji states: 'Faxian received full ordination at the age of twenty, and set out from Chang'an in the third year of Longan, during the Jin'. This means that at the time when Faxian left for his travels, he was at most a little over twenty years old. After sixteen years he returned to the capital, and would have still been younger than forty. Translating the sutras for a few years, he would have been no older than forty-five or forty-six. Liang dynasty monastic biography (i.e. Gaoseng zhuan) has removed the two characters for 'twenty [years old]', in the statement 'received full ordination', and so his age when he set out on his travels is not known.

江陵辛寺法顯 (平陽武陽壟氏). 宋景平元年 (四二三) 以前卒. 傳 記無卒年，惟《出三藏記集》三《彌沙塞律序錄》云：“法顯以晉義 熙十二年還都，眾經多譯，唯《彌沙塞》一部未及譯而亡，至宋景 平元年佛大什出之.' 梁《僧傳》三《佛䭾什傳》同，是法顯卒於 宋景平元年以前也. 又, 法顯年歲, 《出三藏記集》十五作八十二, 《梁僧傳》三作八十六, 似皆不可據. 《出三藏記集》云: “法顯二 
十受大戒, 以晉隆安三年發長安.' 是法顯出游時不過二十餘, 經 十六年還都，不過四十，譯經數年，不過四十五六.《梁僧傳》於 “受大戒” 上刪 ‘二十’ 兩字, 出遊年歲不明. ${ }^{22}$

Based on Chen Yuan's position as seen above, when Buddhajīva arrived in Yangzhou on the first year of Jingping during the Song dynasty (423 CE) and began translating the Wufen lü 五分律 (Five-Part Vinaya; Skt. Pañcavargika-vinaya) brought back by Faxian, Faxian had already passed away. Chu sanzang ji ji records Faxian's death at the age of eighty-two. Following this general position, Gaoseng zhuan of the Liang period made a slight adjustment to his passing at the age of eighty-six. If so, Faxian would have been sixty years old when he set out to the West, which does not sound plausible. Hence, based on reading the context of the passage in the biography, Chen Yuan speculated that shortly after receiving full ordination at age twenty in 399 CE, Faxian set out for the West in search of the Dharma. This proposition is probable. When Faxian went to India, he was travelling along with many colleagues, who appeared to be setting out in their prime instead of in their old age. If this is the case, Faxian's birth year would be before $380 \mathrm{CE}$, which meant he would have lived until his forties, fifties, or slightly older.

However, Chen Yuan did not have any textual evidence to support his proposition that Faxian lived until his forties or fifties. Hence, it was an unconvincing argument. Furthermore, the basis for Chen Yuan's proposition of Faxian's death in $423 \mathrm{CE}$ is worth further discussion. According to the Chu sanzang $j i j i$ :

Faxian returned to the capital in the second year of Yixi, during the Jin. He was very old in years, and made many translations of a number of sutras, but only one text, the Misha lü, was lost (or: he died) before it was translated. In the seventh month of the first year of Jingping, during the Song, the Vinaya master Buddhajīva, from Kashmir, arrived in the capital city. At the end of the eleventh month of that year, Wang Lian from Langya, and the monks Shi Huiyan

22 Chen, Shishi yinian lu, 9. 
and Zhu Daosheng, invited the foreign śramana Buddhajīva to recite (or: translate) it at Longguang Monastery. At the time, Buddhajīva held the foreign text in his hands, and the Khotanese śramana Zhisheng was the translator. It was completed in the twelfth month of the next year.

法顯以晉義熙二年還都，歲在壽星，眾經多譯，唯《彌沙塞》一部 未及譯出而亡. 到宋景平元年七月, 有罚賓律師佛大什來至京都. 其年冬十一月，琅㑚王練、比丘釋慧嚴、笂道生於龍光寺請外國 沙門佛大什出之. 時佛大什手執胡文, 于闐沙門智勝為譯, 至明年 十二月都訖. ${ }^{23}$

In this passage, there appears to be two interpretations for the word 'wang' 亡 in 'was lost (or: he died) before it was translated' 未 及譯出而亡. It could either refer to Faxian passing away before the translation was completed, or that the Mishasai lü 彌沙塞律 was lost before it was translated. If it was the latter, then the word ' $c h u$ ' 出 from 'chuzhi' 出之 would mean to 'recite' instead of to 'translate'. This would mean that Daosheng 道生 and others invited Buddhajīva to recite the Mishasai lü in order to confirm the foreign text in question. Buddhajīva was a Vinaya master from Kashmir. 'He received the precepts from the Mahīsāsaka Sangha and he specialized in the Vinaya texts' (少受業於彌沙塞部僧, 專精律品). ${ }^{24}$ Hence, it is reasonable that he was able to recite Vinaya texts. As a matter of fact, it was Zhisheng 智勝, a Khotanese śramana, who was translating and not Buddhajīva. Therefore, it would make more sense to say that the Mishasai lü brought back by Faxian was lost before it was translated, as if the foreign text was extant, then it could explain neither that Buddhajīva 'recited' nor 'translated' the Mishasai lü.

The passage quoted earlier from Chu sanzang ji ji, juan 3, should be the source of all relevant records from other extent texts, or 'the source of historical material' as Chen Yuan put it. Daosheng's biography in the Chu sanzang $j i j i$ states:

\footnotetext{
23 Su and Xiao, Chu sanzang ji ji, 120.

24 Tang, Gaoseng zhuan, 96.
} 
Initially, the śramana Faxian received the Sanskrit text of the Mishasai lü in the country of Sri Lanka, but the text was lost (or: he died) before it was translated. Starting in the eleventh month of the first year of Jingping, during the Jin, at Longguang Monastery, the Kashmiri Vinaya master Buddhajiva held the Sanskrit text, and the Khotanese śramana Zhisheng was the translator. This Vinaya illuminates the task of surpassing rebirth.

初沙門法顯於師子國得《彌沙塞律》梵本, 未及譯出而亡. 生以宋 景平元年十一月，於龍光寺請睮賓律師佛大什執梵文，于闐沙門 智勝為譯. 此律照明, 蓋生之功也. ${ }^{25}$

The above passage from 'Daosheng zhuan' in Chu sanzang ji $j i$ basically follows the description in juan 3 without considerable changes. Huijiao 慧皎 removed the relevant section from the biography of Daosheng in the Gaoseng zhuan, but added in the biography of Buddhajīva (Chu sanzang ji ji does not have an independent biography for Buddhajīva), stating:

First, the śramana Faxian received the Sanskrit text of the Mishasai lü (Skt. Mahiśsásaka-vinaya) in the country of Sri Lanka. But Faxian passed away before it was translated. The monks in the capital city heard that Buddhajiva was skilled in this field of learning, and so invited him to translate (or: recite) it. In the eleventh month of the same year, they gathered at Longguang Monastery, and translated it into thirty-four juan, calling it the Wufen lü. Buddhajīva held the Sanskrit text, the Khotanese śramana Zhisheng was the translator, Daosheng from Longguang and Huiyan from Dongan both wrote it down and made corrections, and Chizhong from Song and Wang Lian from Langya were the sponsors. In the fourth month of the next year it was completed. At that time, a large quantity of transcribed texts like the heart of the precepts, repentance texts and others were still in circulation. After Buddhajīiva, it is not known what happened to them.

$25 \mathrm{Su}$ and Xiao, Chu sanzang ji ji, 572. 
先沙門法顯，於師子國得《彌沙塞律》梵本，未被翻譯，而法顯遷 化. 京邑諸僧聞什既善此學, 於是請令出焉. 以其年冬十一月集於 龍光寺，譯為三十四卷，稱為五分律。什執梵文，于闐沙門智勝為 譯, 龍光道生、東安慧嚴共執筆參正, 宋侍中琅現王練為檀越, 至 明年四月方竟. 仍於大部抄出戒心及羯磨文等. 並行於世. 什後不 知所蹤. ${ }^{26}$

Huijiao made some alterations in Gaoseng zhuan when retelling the account seen in the passage above. Terms like 'foreign text' 胡 本, found in Chu sanzang ji ji, were changed to 'Sanskrit text' 梵本, and 'wang' 亡 [died] was changed to 'qianbua' 遷化 [passed away]. However, it is questionable if these alterations made by Huijiao in Gaoseng zhuan had any basis. Changing 'wang' to 'qianbua' meant to interpret 'wang' as Faxian's passing. This directly impacts Chen Yuan's position that Faxian passed away at the latest on the first year of Jingping during the Liu Song period (423 CE).

However, as mentioned earlier, it would be more reasonable to explain 'wang' as meaning that the Mishasai lü brought back by Faxian was 'lost' before it was translated. This interpretation would also make it easier to understand the function of Buddhajīva 'chu' 出 [reciting] the Vinaya. Furthermore, taking the latest year for Faxian's death as $423 \mathrm{CE}$ and that Faxian was quite long lived, over eighty years of age, this would entail that when Faxian set out from Chang'an to travel to the West in $399 \mathrm{CE}$, he would have already been about sixty years old, which is not very reasonable.

In our view, there is some circumstantial evidence indicating that Faxian was still alive after $423 \mathrm{CE}$. Faxian's biography in Gaoseng zhuan contains records about what happened after Faxian's return to China:

Going south, he reported to the capital that at Daochang Monastery the foreign Chan master Buddhabhadra had translated the Mohe sengqi lü (Skt. Mabāsāingha-vinaya), Fangdeng nibuan jing (Skt. Mabāparinirvāna-sūtra) and $\mathrm{Za}$ apitan xin (Samyuktābhidharmabrdaya-śāstra), putting these down in over one million words.

\footnotetext{
26 Tang, Gaoseng zhuan, 96.
} 
遂南造京師, 就外國禪師佛䭾跋陀於道場寺, 譯出《摩訶僧祇律》、 《方等泥洹經》、《雜阿毗曇心》垂百余萬言. ${ }^{27}$

Relevant records found in Faxian's biography in the Chu sanzang ji ji are as follows:

Going south, he reported to the capital that at Daochang Monastery the foreign Chan master Buddhabhadra had translated the Nibuan [jing] (Skt. Nirvannasütra) in 6 juan, the Mohe sengqi lü, Fangdeng nibuan jing (Skt. Mahäparinirvāna-sūtra), Yan jing [Tassel Sutra] and $Z a$ apitan xin (Skt. Samyuktäbhidharma-hrdaya-sástra). There were over one million words in texts not yet translated.

遂南造京師, 就外國禪師佛䭾咙陀羅, 於道場寺譯出六卷《泥洹》、 《摩訶僧祇律》、《方等泥洹經》,《綖經》、《雜阿毗罢心》未及譯 者, 垂有百萬言. ${ }^{28}$

Also, the following is recorded in the Chu sanzang ji $j i$ :

Da bannibuan jing [Great Parinirvāna Sutra; Skt. Mahāparinirvāna-sūtra], 6 juan (translated at Daochang Monastery, first day of the eleventh month of the thirteenth year of Yixi, during the Jin). 《大般泥洹經》六卷 (晉義熙十三年十一月一日, 道場寺譯).

Fangdeng nibuan jing [Expansive Parinirvāna Sutra; Skt. Mahāparinirvāna-sūtra], 2 juan (now missing). 《方等泥洹經》二卷 (今 閶).

Mohe sengqi lü [Mahāsānghika Vinaya; Skt. Mahāsānghba-vinaya], 40 juan (already included in the Vinaya records) 《摩訶僧祇律》四十 卷 (已入律錄) .

27 Tang, Gaoseng zhuan,90.

$28 \mathrm{Su}$ and Xiao, Chu sanzang ji ji, 576. 
Sengqi biqiu jieben [Mahāsānghika Monks Precepts; Skt. Mahāsamgha-bhikșuñ-vinaya], 1 juan (now missing)《僧祇比丘戒 本》一卷 (今關).

Za apitan xin [Heart of the Assorted Abhidharma; Skt. Samyuktābbidharma-brdaya-sástra], 13 juan (now missing)《雜阿毗昙心》 十三卷 (今關) .

Za zang jing [Assorted Canon Sutra; Skt. Samyukta-pitaka-sūtra], 1 juan 《雜藏經》一卷.

Yan jing [Tassel Sutra] (Sanskrit text, not translated)《綖經》 (梵文, 未譯出).

Chang aban jing [Long Discourses Sutras; Skt. Dīrghāgama-sūtra] (Sanskrit text, not yet translated).《長阿含經》

（梵文, 未譯）。

Za ahan jing [Assorted Discourses Sutras; Skt. Samyuktāgama-sūtra] (Sanskrit text, not yet translated)《雜阿含經》(梵文, 未譯）。

Mishasai lü [Mahís̄āsaka Vinaya; Skt. Mahissásaka-vinaya] (Sanskrit text, not yet translated). 《彌沙塞律》(梵文, 未譯).

Sapoduo lü chao [Sarvāstivāda Vinaya Redaction] (Sanskrit text, not yet translated). 《薩婆多律抄》(梵文, 未譯).

Fo you Tianzhu ji [Records of the Buddha's Travels in India], 1 juan. 《佛遊天竺記》一卷.

Of the first eleven texts, six texts were definitely translated, into a total of 63 juan. During the time of Jin emperor An, the śramana Shi Faxian travelled to the Western regions in the third year of Longan, received foreign texts in central India and Sri Lanka, returned to the capital, and lived in Daochang Monastery. They were translated with the Indian Chan master Buddhabhadra. The 
Chang [Ahan jing] (Skt. Dïrghägama-sütra) and Za [Ahan jing] (Skt. Samyuktāgama-sūtra), Yan jing, Mishasai lü (Skt. Mahīsásaka-vinaya) and Sapoduo lü chao are Sanskrit texts, and have not yet been translated.

右十一部, 定出六部, 凡六十三卷. 晉安帝時, 沙門釋法顯以隆安 三年游西域，於中天笂、師子國得胡本，歸京都，住道場寺。就天 竺禪師佛䭾跋陀共譯出. 其《長雜二阿含》、《綖經》、《彌沙塞律》、 《薩婆多律抄》, 猶是梵文, 未得譯出. ${ }^{29}$

It is likely that when modern editors punctuated Chu sanzang ji $j i$, they based it on the above passage, especially the records that Yan jing was not translated. Hence, they added a joining comma instead of a listing comma between the Fangdeng nibuan jing (Skt. Mahāparinirvāna-sütra) and Yan jing. They considered that Nibuan (Skt. Nirvānasūtra), Mohe sengqi lü (Skt. Mahāsāingha-vinaya) and Fangdeng nibuan jing (Skt. Mahāparinirvāna-sütra) were translated, while Yan jing and $Z a$ apitan xin (Skt. Samyuktäbhidharmabrdaya-śästra) were part of untranslated texts in one million words. However, the literal meaning when punctuated this way is very strange:

at Daochang Monastery, translated the Nibuan [jing] in 6 juan, the Mohe sengqi lü (Skt. Mahāsāingha-vinaya) and Fangdeng nibuan jing (Skt. Mahäparinirvāna-sütra). The Yan jing and $Z a$ apitan xin were texts not yet translated with over one million words.

於道場寺譯出六卷《泥洹》、《摩訶僧祇律》、《方等泥洹經》, 《綖 經》、《雜阿毗曇心》未及譯者, 垂有百萬言.

Classical Chinese does not itself have sentence punctuation, and if the original author wished to convey this meaning, it would be almost impossible to adopt such a sentence structure. Thus, we believe that a more appropriate way of punctuating would be:

29 Su and Xiao, Chu sanzang ji ji, 55 . 
at Daochang Monastery, translated the Nibuan jing in 6 juan, the Mohe sengqi lü, Fangdeng nibuan jing, Yan jing and Za apitan xin. There were over one million words in texts not yet translated.

於道場寺譯出六卷《泥洹》、《摩訶僧祇律》、《方等泥洹經》、 《綖經》、《雜阿毗曇心》.未及譯者, 垂有百萬言.

The passage quoted earlier from juan 2 of Chu sanzang ji ji concerning records on Faxian's translation of scriptures is very old. It does not reflect the situation after 423 CE. However, Mishasai lü should have already been translated by $423 \mathrm{CE}$. Yet, it was stated in juan 2 of Chu sanzang ji ji that it has 'not yet been translated'. In comparison, Faxian's biography in the Chu sanzang ji ji may reflect a later situation, that Yan jing and $Z a$ apitan xin were already translated when Faxian was still alive.

The ' $Z a$ apitan xin xü' 雜阿毗昙心序 [Preface to the Heart of the Assorted Abhidharma] by an 'unknown author' 未詳作者 in the Chu sanzang ji ji states:

In the third year of Yuanjia, during the Song, the magistrate of Xuzhou, Wang Zhongde of Taiyuan, invited the foreign śramana Ísvara to Pengcheng to translate it. Half of the 'Ze pin' and the whole of the 'Lun pin' were not completed due to circumstances which arose. By the eighth year of Yuanjia, there was another Dharma master from India, named Gunabhadra, who had attained the path of stream entry and was well trained in this text. He came on his travels to Yangdu, where he further revised the text and explained in detail its main teachings. The remainder was clearly appended at the end of the two compilations, a written record of what was heard of his teachings. Fortunately for readers, this was still of considerable benefit.

於宋元嘉三年, 徐州刺史太原王仲德請外國沙門伊葉波羅於彭城 出之. 《擇品》之半及《論品》一品, 有緣事起, 不得出竟. 至元嘉 八年, 復有天竺法師名求那咙摩, 得斯陀含道, 善練茲經, 來遊揚 都, 更從校定, 諮詳大義. 餘不以闇短, 廝在二集之末, 輙記所聞, 以訓章句, 庶於覽者, 有過半之益耳..$^{30}$ 
Also in the same juan, Venerable Jiaojing's 焦鏡 'Houchu za xin xu' 後出雜心序 (Preface to lately translated Samyuktābhidharmabrdaya-śāstra [Assorted Abhidharma]) states:

In the eleventh year of Yuanjia, Jiaxu, during the Song, there was a foreign śramana named Tripitaka who toured and travelled here. He previously studied this sutra comprehensively in the great country [of India], and so the Sangha community invited him to recite it. Then, in the ninth month of that year, scholars gathered at Zhanggan Monastery in the Song capital, where Venerable Yun'gong translated the words and Venerable Guanggong recorded it. After revision and ratification, it took a whole year to complete. Due to lack of ability, Jiaojing incorrectly heard some of the end of this, and so although his thinking did not ascertain its mysteries, at times he managed a shallow understanding. Now a careful comparison of all that was heard has been made, in order to direct later generations. A compromise has been made awaiting further wisdom. Composed in the villa of Xu Zhijiang at Mount Shining in Huiji.

於宋元嘉十一年甲戌之歲, 有外國沙門名日三藏, 觀化遊此. 其人 先於大國綜習斯經, 於是眾僧請令出之. 即以其年九月, 於宋都長 幹寺集諸學士，法師雲公譯語，法師觀公筆受. 考校治定，周年乃 訖. 鏡以不才, 謬預聽未, 雖思不及玄, 而時有淺解. 今謹率所聞, 以示後生, 至於折中, 以俟明哲. 於會稽始甯山徐支江精舍撰訖. ${ }^{31}$

From this, we can conclude that $\mathrm{Za}$ apitan xin was translated in the eleventh year of Yuanjia ( $434 \mathrm{CE}$ ). Furthermore, the Sanskrit text, which the translation was based on, did not come from those brought back by Faxian. Trepițaka Gunavarman, arriving in China in the eighth year of Yuanjia (431CE), eventually recited it in full. Gunavarman's biography in the Chu sanzang ji ji describes the same accounts:

30 Su and Xiao, Chu sanzang ji ji, 384-85.

31 Su and Xiao, 385. 
At the start of the third year of Yuanjia, the magistrate of Xuzhou, Wang Zhongde, in Pengcheng invited the foreign śramana Ívara to Pengcheng to translate the Samyuktābhidharma-hrdaya-sástra. When he reached the 'Ze pin' 擇品 [Chapter on Discernment] and it was not yet completed, adverse circumstances occurred that stopped work. Due to this, later Gunavarman was invited to the monastery to further revise and ratify, correcting the sense of the text.

初, 元嘉三年, 徐州刺史王仲德於彭城請外國沙門伊葉波羅譯出 《雜心》, 至《擇品》未竟, 而緣礙遂輟. 至是乃更請咙摩於寺重更 校定, 正其文旨. 32

Records from Guṇavarman's biography in Gaoseng zhuan are basically the same:

At the start of the third year of Yuanjia, the magistrate of Xuzhou, Wang Zhongde, in Pengcheng, invited the foreigner Íśvara to Pengcheng to translate the Samyuktābhidharma-brdaya-sástra. When he reached the 'Zepin', adverse circumstances occurred that stopped work. Due to this, Gunavarman was later invited to translate the latter chapters. When finished it was thirteen juan.

初元嘉三年，徐州刺史王仲德於彭城請外國伊葉波羅譯出《雜 心》. 至《擇品》而緣礙, 遂輟. 至是更請跋摩譯出後品, 足成十三 卷. ${ }^{33}$

The author of 'Houchu za xin xu', 'Venerable Jiaojing' should be referring to Sengjing 僧鏡. Sengjing's biography in the Gaoseng zhuan records that he wrote the text, 'Pitan xuan lun, distinguishing the categories of the doctrines, with a connecting line of thought' (《毗昙玄論》, 區別義類, 有條貫焉). ${ }^{34}$ 'This is just as the 'Houchu za xin xu' states, 'The remainder was clearly appended at

\footnotetext{
32 Su and Xiao, Chu sanzang ji ji, 544.

33 Tang, Gaoseng zhuan, 108.

34 Tang, 293.
} 
the end of the two compilations, a written record of what was heard of his teachings. Fortunately for readers, this was still of considerable benefit' (余不以闇短, 廁在二集之末, 輙記所聞, 以訓章句, 庶於覽者, 有過半之益耳).

In short, the translation of Za apitan xin was completed in $434 \mathrm{CE}$. If Faxian saw the completed translation, this would mean that he was still alive in $434 \mathrm{CE}$. In that case, it would be impossible for him to have died before $423 \mathrm{CE}$.

Just like Chen Yuan's position, it is more reasonable to consider that Faxian left for India shortly after he received full ordination at the age of twenty. Apart from the contextual meaning within the biographies of monastics, after he received full ordination, he 'often lamented that there was material missing from the sutras and Vinaya' (常慨經律多䦕). From the perspective of faith and practice, that the Vinaya precepts in China were incomplete raises the issues of whether or not the precepts Faxian received were legitimate, and if he truly received the precepts. These pressing questions troubled Faxian and became crucial driving forces behind his 'determined vow to seek' 誓志尋求 the precepts in India. Zhiyan 智嚴, a contemporary of Faxian, was doubtful whether he truly received the precepts and went to India in search of resolution. Zhiyan's biography in the Chu sanzang $j i j i$ has the following passage:

Before he renounced he attempted to receive the five precepts, but was remiss and transgressed. Later, when he entered monasticism and received full ordination, he constantly doubted whether or not he had attained the precepts. He was often afraid and so spent years in meditative contemplation, but was unable to resolve it by himself. After he crossed the ocean and reached India, he consulted many experts about this. When he encountered a monk who was an arbat, he asked about this matter. The arbat did not venture a judgement on the matter, but entered meditation and, on behalf of Zhiyan, went to the Tusita palace to ask Maitreya. Maitreya answered that Zhiyan attained the precepts. Zhiyan was joyous to hear this, and left.

其未出家時, 嘗受五戒, 有所雐犯. 後入道受具足, 常疑不得戒, 每 以為懼, 積年禪觀, 而不能自了. 遂更泛海, 重到天笂, 諮諸明達. 
值羅漢比丘, 具以事問羅漢. 羅漢不敢判決, 乃為嚴大定, 往淣率 宮諮彌勒. 彌勒答稱得戒. 嚴大喜躍, 於是步歸. ${ }^{35}$

Records from Zhiyan's biography in the Gaoseng zhuan are the same as the passage above. Zhiyan was doubtful whether he truly received the precepts. 'He crossed the ocean and reached India, he consulted many experts about this' (遂更泛海, 重到天䇥, 諮諸明達). ${ }^{36} \mathrm{It}$ is likely that Faxian was in similar circumstances. He bemoaned that the precepts were incomplete after he received full ordination, then left for India in search of Vinaya not long after that (after many years or a few years.) From this, we can deduce that Faxian was in his twenties in $399 \mathrm{CE}$, which meant that he was born in the 370s, lived for over eighty years, and passed away in the 450s.

If Faxian was born in the 370s, then it was earlier than Xie Lingyun 謝靈運, who was born in 385 CE. Zhong Rong’s 鐘㷋 Shi pin 詩品 [Ranking Poetry], juan 1, 'Chapter on Xie Lingyun, Governor of Linchuan during the Song', records the following: 'There were few sons and grandsons in his family, so Lingyun was sent to a Daoist temple to be raised. He only returned [home] at the age of fifteen, and was thus named 'visitor son" (其家以子孫難得, 送靈運 於杜治養之, 十五方還都, 故名 “客兒” ). ${ }^{37}$ Xie Lingyun received the novice precepts around the same period, but at a slightly later time than Faxian. Daoists also had the religious custom of sending young children to be raised in the Libation Bureau until they reached adulthood in order to seek long life.

\section{Xin Monastery and Faxian's Vinaya Propagation Activities} Later in Life

According to records in Chu sanzang ji ji and Gaoseng zhuan, Faxian passed away in Xin Monastery in Jingzhou. Xinsi 辛寺 [Xin Monas-

\footnotetext{
35 Su and Xiao, Chu sanzang ji ji, 577.

36 Tang, Gaoseng zhuan, 100.

37 Siku quanshu, 1478: 193.
} 
tery] is sometimes written as ' $X i n s i$ ' 新寺 [Xin Monastery]. The earliest record of Xin Monastery we can find comes from a late fourth century Dunhuang text, written approximately between the sixth month of the eighth year of Taichu (395 CE) and the seventh month of the thirteenth year ( $400 \mathrm{CE}$ ) during the Western Qin. The translation notes of Foshuo Mohe chatou jing 佛說摩訶刹頭經 [Buddha Teaches the Mahāsattva Sutra; Skt. Mahāsattva-sūtra] state, 'In the Western Qin, during the Taichu period, at the Qifu capital of Wanzhou. Translated by the śramana Shengjian at Xin Monastery in Jiangling, and recorded by Yu Shuang' (右西秦太初年, 乞伏氏都莞 川, 沙門聖堅於江陵辛寺譯. 庵爽筆). ${ }^{38}$

If Faxian passed away in the 450s, then it would be at the time of Prince Qiao's rebellion or earlier. Prince Qiao was Xin Monastery's biggest donor in the middle of the fifth century. Prince Qiao was Liu Yixuan 劉義宣, the Prince of Nanqiao. His biographical records are found in Song shu 宋書 [Book of Song]. Qiunabatuoluo's (Gunabhadra 求那跋陀羅) biography of him in the Chu sanzang ji ji says:

Later, Prince Qiao was stationed at Jingzhou, and invited him to travel together. They stayed at Xin Monastery, for which a new residence was created. It was at Xin Monastery that a number of sutras were translated, namely, Wuyou wang [jing] (Skt. Asokasütra), Guoqu xianzai yinguo [Cause and effect between past and present] and Wuliang shou (Sukhāvatì-vyüha-sütra) in one juan, Nibuan [jing] (Skt. Nirvāna-sūtra) in one juan, Yangjuemo (Skt. Angulimālīya-sūtra), Xiangxu jietuo (Skt. Samdhinirmocana-sūtra), Boluomi liaoyi (Skt. Pāramitā-sūtra), Diyi yi wu xiang lue (Skt. Paramārtha-pañca-lakșana-sūtra), Ba jixiang (Skt. Asțabuddhaka-sūtra) and others, in a total of over one hundred juan.

後譙王鎮荊州，請與俱行，安止辛寺，更創殿房. 即於辛寺出《無 憂王》、《過去現在因果》及一卷《無量壽》、一卷《泥洹》、《央掘

\footnotetext{
38 Wang and Li, Wei jin nanbeichao Dunbuang wenxian biannian, 106-07.
} 
魔》、《相續解脫》、《波羅蜜了義》、《第一義五相略》、《八吉祥》 等諸經, 凡一百餘卷. 39

The corresponding records from 'Qiunabatuoluo zhuan' in Gaoseng zhuan are basically the same. ${ }^{40}$ Also, in the Meisō den shō 名 僧傳抄 [Redaction of the Mingseng zhuan (Biographies of Famous Monks)], it is said:

Previously, in the twenty-third year of Yuanjia, Prince Qiao was stationed at Jingzhou, and invited him to travel together. They stayed at Xin Monastery, for which a new residence was erected. It was in the monastery that he translated the Asoka-sūtra (Wuyou wang jing) in one juan, Asțabuddhaka-sütra (Ba jixiang jing) in one juan, Guoqu xianzai yinguo [Cause and effect between past and present] in four juan, Wuliang shou (Sukhāvatì-vyūha) in 1 juan, and Nibuan [jing] (Nirvāna-sütra) in one juan, a total of thirteen texts for a combined 73 juan.

先自元嘉二十三年，譙王鎮荊洲，請與俱行，安顋辛寺，更立殿 房. 即於寺內, 出《無憂王經》一卷、《八吉祥經》一卷、《過去現 在因果》四卷、《無量壽》一卷、《泥洹》一卷，凡十三部，合七十 三卷. ${ }^{41}$

Records from Gaoseng zhuan indicate that Liu Yixuan was stationed at Jingzhou in the twenty-third year of Yuanjia (446 CE). Liu Yixuan's 劉義宣 biography in the Song shu dates it to the twenty-first year of Yuanjia (444 CE):

Initially, Gaozu used the excellent location up river from Jingzhou, where the ground was broad and the troops strong. He issued a posthumous edict that his sons take turns to reside there. ... In the twenty-first year (of Yuanjia), [Liu] Yixuan was commander of mili-

\footnotetext{
$39 \mathrm{Su}$ and Xiao, Chu sanzang ji ji, 548 .

40 Tang, Gaoseng zhuan, 121.

${ }^{41} X$ no. 77: 351 .
} 
tary affairs for the seven provinces of Jing, Yong, Yi, Liang, Northern and Southern Qin, chariot general and magistrate of Jingzhou. He upheld the festivals and duties as in ancient times.

初, 高祖以荊州上流形勝, 地廣兵強, 遺詔諸子次第居之...... (元 嘉）二十一年, 乃以義宣都督荊、雍、益、梁、甯、南北秦七州諸 軍事、車騎將軍、荊州刺史, 持節、常侍如故. ${ }^{42}$

During [Liu] Yixuan's ten years of station, the army was strong and there was plentiful wealth. He thereupon set out upon the path of virtue, proclaiming to all beneath heaven that whatever they wished for, it would all be granted. Only matters that did not conform to the rules and regulations of the imperial palace would not be permitted.

義宣在鎮十年, 兵強財富, 既首創大義, 威名著天下, 凡所求欲, 無 不必從. 朝廷所下制度, 意所不同者, 一不遵承.43

Liu Yixuan was very generous with his offerings to Xin Monastery. It was noted in Gaoseng zhuan that Gunabhadra 'received offerings for ten years' (受供十年) ${ }^{44}$ at Xin Monastery, Jingzhou.

Liu Yixuan also adored luxury:

When Yixuan started his station, he was industrious in exhorting himself, and made improvements in administrative matters. Fair skinned, with beautiful hair and beard, he stood 1.75 meters tall, and wore a large belt. He kept many concubines and maids, over one thousand in the inner chambers, as well as several hundred nuns, and thirty male and female [servants]. He was lavish and luxurious, broadly spending a great deal of wealth.

義宣至鎮, 勤自課庽, 政事修理. 白晳, 美鬚眉, 長七尺五寸, 腰帶

\footnotetext{
42 Song shu 68.1798.

43 Song shu 68.1800.

44 Tang, Gaoseng zhuan, 133.
} 
十圍, 多畜嬪媵, 後房千餘, 尼媼數百, 男女三十人. 崇飾綺麗, 費 用殷廣. ${ }^{45}$

In $545 \mathrm{CE}$, Liu Yixuan was killed after his rebellion was defeated. After his defeat, Gunabhadra, who was in Xin Monastery at the time, was implicated and taken prisoner during the chaos. Faxian may have died under such circumstances, or he may have passed away slightly before this time. Xin Monastery would have been greatly impacted during Prince Qiao's rebellion, and hence records of Faxian's death year and his engagements in his later years are unclear. Tanwujie 昙無 竭 (Fayong 法勇), 'once had heard that Faxian and others personally walked to the land of the Buddha, and forsaking attachment vowed to offer up his own life' (嘗聞法顯等躬踐佛國, 乃慨然有忘身之誓). He also travelled to the West in search of the Dharma. He stayed in Xin Monastery in his later years. His situation might be similar to that of Faxian, that 'his eventual fate was unknown after (Prince Qiao's rebellion)' (後不知所終 ${ }^{46}$.

Furthermore, the issues of when and why Faxian left the Southern dynasties' capital of Jiankang for Xin Monastery in Jingzhou are also worth investigating. According to his Faxian zhuan (Foguo ji), after Faxian returned to China, he was going to go back up north to Chang'an:

Faxian had been away from his teachers for a long time, and wished to return to Chang'an. However, his burdens were heavy, and so he went south toward the capital. There, together with the Chan master (Buddhabhadra), he translated sutras and Vinaya.

法顯遠離諸師久, 欲趣長安. 但所營事重, 遂便南下向都, 就禪師 (佛陀跋陀羅) 出經律. ${ }^{47}$

\footnotetext{
45 Song shu 68.1799.

46 Tang, Gaoseng zhuan, 93-94. The main biographical materials in Gaoseng zhuan do not mention the relationship between Tanwujie and Xin Monastery. This can be demonstrated through further research. However, since it is not directly related to the current paper, we will not cover it here, but in another paper.
} 
In addition, Faxian went down south at the invitation of Lushan Huiyuan 盧山慧遠. He accepted the invitation and composed the Faxian zhuan (Foguo ji):

The man of the way, Faxian, was welcomed in the fifty-first year of the cycle, the twelfth year of Yixi, during the Jin ( $416 \mathrm{CE})$, in the time of Shouxing, at the end of the summer retreat. After he arrived, he stayed there until the winter feast. Due to giving lectures to assemblies of people, he was repeatedly asked about his travels. He was respectful and acquiesced to these requests, and his responses were always factual. Due to this, things previously mentioned only in brief were now given in detail. Faxian would again narrate them from start to finish.

是歲甲寅. 晉義熙十二年 (416年), 歲在壽星, 夏安居末, 迎法顯 道人. 既至, 留共冬齋. 因講集之際, 重問遊歷. 其人恭順, 言輙依 實. 由是先所略者, 勸令詳載. 顯復具敘始末. 48

Hence we can conclude that after returning to China, Faxian planned to go to Chang'an. However, he was unable to do so due to reasons like the chaos of wars in the north. (In $417 \mathrm{CE}$, Liu Yu from the south regained Chang'an, and Yao Qin was destroyed. In 418 CE, Guanzhong was attacked by Helian Bobo 赫連勃勃. Chang'an fell under the attack, the north was in turmoil, and monastics in the north dispersed in all directions.) Faxian left Jiankang for Jingzhou in early-mid 420s, he may have intended to travel further north. In addition, we know for a fact that in 418 CE Buddhabhadra trans-

\footnotetext{
47 Zhang, Faxian zhuan jiaozbu, 150.

48 Zhang, 153. Based on this, Zhang Xun (Zhang, Faxian zbuan jiaozbu, 154) argues that Lushan Huiyuan's death date should be the sixth of the eighth month, in the thirteenth year of Yixi (417 CE), as recorded in Guang Hongming $j i$ 廣弘明集, juan 23, Xie Lingyun's 'Lushan Huiyuan fashi lei’ 盧山慧遠法師昩 [Venerable Lushan Huiyuan's Eulogy], not in the twelfth year of Yixi as mentioned in 'Lushan Huiyuan zhuan'盧山慧遠傳 [The Biography of Lushan Huiyuan], in Gaoseng zhuan.
} 
lated the Mahāsāingha-vinaya brought back by Faxian at Daochang Monastery in Jiankang. This led to the protracted debate on squatting to eat centred at Zhihuan Monastery. ${ }^{49}$ The early-mid period of the 420 s was also the height of the debate on squatting to eat. Since Faxian brought Mahāsāngha-vinaya to China, no doubt he was one of the focal points in this debate. In response to this debate, Faxian may have chosen to avoid it by leaving the centre of the debate, and so left Jiankang for Jingzhou. Faxian must have left Jiankang slightly earlier than $423 \mathrm{CE}$, which was when the Mabiśasaka-vinaya (that is, Skt. Pañcavargika-vinaya) was translated into Chinese as Wufen lü, as discussed earlier.

Faxian left Jiankang before many of the Sanskrit texts he brought back were translated. He may have kept these Sanskrit texts in Jiankang instead of bringing them with him to Xin Monastery in Jingzhou. Hence, he must have discontinued his translation activities after the early-mid 420s. Since all the untranslated Sanskrit texts brought back by Faxian were left in Jiankang, it would mean that the records on Faxian's list of scriptures in juan 2 of Chu sanzang ji ji, discussed previously, would also have stopped before he left Jiankang for Xin Monastery in Jingzhou.

Regarding the debate on squatting to eat, it was clear that Faxian was not as enthusiastic as Daosheng and others who pushed for the translation of Pañcavargika-vinaya. However, Faxian was not being totally passive and evasive when choosing to go to Xin Monastery in Jingzhou. He went there because of something that appealed to him, namely, that Xin Monastery in Jingzhou was the centre of Kumārajīva's newly translated text, Shisong lü 十誦律 [Ten-Recitations Vinaya; Skt. Daśabhānavāra-vinaya]. Beimoluocha’s 卑摩羅叉 (Vimalākṣa) biography in the Gaoseng zhuan states:

Vimalākṣa ... arrived in Guanzhong during the eighth year of Hongshi, during the Qin (406 CE). Kumārajīva respectfully hosted him with a teacher's courtesy, and Vimalākșa was also delighted to meet him from afar. When Kumārajīva left the world, Vimalākșa then

\footnotetext{
49 Yoshikawa, Liuchao jingshen shi yanjiu, 115-27; Chen, 'Qihuan si', 38-54.
} 
travelled to the east of Guangzhong, remaining in Shouchun and staying in Shirun Monastery. There the precept community gathered from afar and expounded on the Vinaya. The Shisong lü translated by Kumārajīva was fifty-eight juan, and the last recitation explained the method of receiving the precepts as well as matters for accomplishing wholesome practices. It was named the 'Shan song' in accordance with this essential content. Vimalākșa later sent it to Shirun, where it became sixty-one juan. The last recitation was changed to the 'Pini song', and that is why both these names are still extant.

卑摩羅叉....... 以偽秦弘始八年達自關中, 什以師禮敬待, 叉亦以 遠遇欣然. 及羅什棄世, 叉乃出遊關左, 逗於壽春, 止石澗寺, 律眾 雲聚, 盛闡毗尼. 羅什所譯《十誦》本, 五十八卷, 最後一誦, 謂明 受戒法, 及諸成善法事, 逐其義要, 名為《善誦》. 叉後齍往石澗, 開為六十一卷, 最後一誦, 改為《毗尼誦》, 故猶二名存焉.

Not long after, he went south to Jiangling, and dwelt at Xin Monastery for the summer, lecturing on the Shisong $l \ddot{u}$. He mastered the language of Han Chinese and was of acceptable and pleasant appearance, so he did not make a manuscript, but expounded it directly. Those who analysed the text and sought its principles gathered like a thicket. Those who knew the rules and understood the proscriptions were countless in number. The great propagation of the Vinaya canon was due to the efforts of Vimalākșa. Huiguan from Daochang [Monastery] deeply upheld the key principles and recorded the severity of the inner proscriptions in the regulations. This was written down in two juan and sent back to the capital. The monks and nuns there studied and expanded upon it, and competed to write essays about it. Those who heard it coined a saying: 'Vimalākșa's crude words became Huiguan's skilled record. The people of the capital transcribed it, and paper became as costly as jade.' It is now presently in circulation and will be the Dharma for later generations.

頃之, 南適江陵, 於辛寺夏坐, 開講《十誦》. 既通漢言, 善相領納, 無作妙本, 大闡當時. 析文求理者, 其聚如林; 明條知禁者, 數亦 殷矣. 律藏大弘, 叉之力也. 道場慧觀深括宗旨, 記其所制內禁輕 重, 撰為二卷, 送還京師. 僧尼披習, 競相傳寫. 時聞者諺日: “卑 
羅鄙語, 慧觀才錄. 都人繥寫, 紙貴如玉.' 今猶行於世, 為後生法 矣..$^{50}$

After Kumārajīva passed away, Vimalākṣa was the most influential proponent of Shisong lü. He 'expounded it directly' 大闆當時 at Xin Monastery. Furthermore, due to Huiguan’s 慧觀 propagation, it had a huge impact in the capital, Jiankang. That Faxian went to Xin Monastery in Jingzhou during this time may be closely related to studying the Shisong lü.

Many monastics were very accomplished after learning Shisong lü from Vimalākșa in Xin Monastery. Huiyou’s 慧猷 biography in the Gaoseng zhuan states:

Shi Huiyou was from Jiangzuo. He renounced at a young age, dwelling at Xin Monastery in Jiangling. As a child he was a practicing vegetarian, and his character was very upright and proper. After receiving the precepts, he focused on the Vinaya rules. Once, when the Western Vinaya master Vimalākșa came to Jiangling to broadly propagate the Vinaya canon, Huiyou received teachings from the master. Contemplating on it for quite some time, he became very wise concerning the Daśabhānavāra-vinaya. Lecturing and teaching it continuously, there was not a single Vinaya master in Shaanxi that did not take his teachings as a model. Later, he died in Jiangling. He composed the Shisong yishu (Commentary to the Shisong lï) in eight juan.

釋慧猷, 江左人. 少出家, 止江陵辛寺. 幼而疏食履操, 至性方直. 及具戒已後, 專精律禁. 時有西國律師卑摩羅叉, 來適江陵, 大弘 律藏, 奠從之受業. 沉思積時, 乃大明《十誦》, 講說相續, 陝西律 師莫不宗之. 後卒於江陵, 著《十誦義疏》八卷. ${ }^{51}$

Also, in Tanbin's 曇斌 biography of the Gaoseng zhuan:

Shi Tanbin, lay surname Su, was from Nanyang. He renounced

\footnotetext{
50 Tang, Gaoseng zhuan, 63-64.

51 Tang, Gaoseng zhuan, 428.
} 
at the age of ten, and served his teacher Daoyi. Initially he lived in Xin Monastery in Jiangling, listening to the sutras and treatises, and learning the way of Chan meditation. ... He took his walking staff and fastened his robes, travelling to different lands to ask about the way. First, he proceeded to the capital, and then went to Wu prefecture. He encountered Sengyie teaching the Shisong lï, and on listening for a short time had a deeply penetrating realization.

釋昙斌, 姓蘇, 南陽人. 十歲出家, 事道禕為師. 始住江陵新寺, 聽 經論, 學禪道......振錫挾衣, 殊邦問道. 初下京師, 仍往吳郡. 值 僧業講《十誦》, 餐聽少時, 悟解深入. 52

Records from the Meisō den shō indicate that Tanbin went to Xin Monastery in Jiangling in the second year of Yuanjia (425 CE). It is closer to our argument about the year Faxian went to Xin Monastery:

[Tanbin's] original family name was Su. He was from Nanyang. (Wang Jing states that he was from the capital.) He renounced when over ten years old, and served the śramana Daoyi as his disciple. He was afflicted with a foot disease, and did not venture to travel to the capital. In the second year of Yuanjia he went to Jiangling, and lived in Xin Monastery, hearing the sutras and treatises, as well as cultivating Chan meditation and precepts. On visiting the capital, he encountered the Vinaya master Sengyie, who was at Wu lecturing on the Shisong lï. He immediately went there and listened to him, and after it was over he returned to the capital.

本姓蘇, 南陽人也 (王巾云京兆人也) 。年十餘出家, 事沙門道禕為 弟子. 患腳疾, 不敢下都. 元嘉二年, 乃往江陵, 咊於辛寺, 飡聽經 論, 兼修禪律...... 因下京都, 值僧業律師, 在吳講十誦, 即往就聽, 事竟還都. ${ }^{53}$

At the time, many monastics who were upholding the Vinaya

52 Tang, Gaoseng zhuan, 290.

53 no. 77: 354 . 
went south to Xin Monastery in Jingzhou after Kumārajīva passed away and Yao Qin was destroyed. Tanjian's 昙鑒 biography in the Gaoseng zhuan states:

Shi Tanjian ... heard that the master Kumārajīva was in Guan[zhong], so followed to study under him. Kumārajīva often said that Tanjian was a person who could hear something once and immediately memorize it. Later, he travelled and taught, reaching Jingzhou, where he dwelt at Xin Monastery in Jiangling. At the ripe old age of sixty years, his diligence became increasingly pure.

釋昙鑒...... 聞什公在關, 杖策從學, 什常謂鑒為一聞持人. 後游方 宣化, 達自荊州, 止江陵辛寺. 年登耳順, 勵行彌潔. 54

Dharmayaśas, who was in Yao Qin, also arrived in Xin Monastery: 'Later, Dharmayaśa travelled south to Jiangling, where he dwelt at Xin Monastery to strongly propagate the Chan teachings'. ${ }^{55}$ 耶舍後 南遊江陵, 止於辛寺大弘禪法. Dharmayaśa had a disciple named Zhu Fadu 笂法度, who specialized in upholding the Hinnayāna precepts. He slandered the Mahāyāna, which had a huge impact at the time. ${ }^{56}$ Sengyou criticized this in his 'Xiaocheng mixue Zhu Fadu zaoyi yi ji' 小乘迷學竺法度造異儀記 [Records on the Hīnayāna Extremist Zhu Fadu's Fabrication of Deviant Practices]. ${ }^{57}$

In short, after Kumārajīva passed away and Yao Qin was destroyed, Xin Monastery in Jingzhou gradually became the centre for the study of Vinaya. This was especially so as Vimalākșa was propagating Shisong lü in Xin Monastery, which became the foremost hub for the study of Shisong lü during the 420s.

It is well knowing that during the Southern and Northern dynasties, the situation of Vinaya in Chinese Buddhism was as follows: the

\footnotetext{
54 Tang, Gaoseng zhuan, 273.

55 Tang, 42.

56 Tang, 42-43. The Gaoseng zhuan biography of Tanmoyeshe 昙摩耶舍 (Dharmayaśas) mentions Zhu Fadu in an appended biography.

57 Su and Xiao, Chu sanzang ji ji, 232-33.
} 
Southern dynasties mainly used Shisong lü, the early-mid period of the Northern dynasties mainly used Mohe sengqi lü, and Sifen lü 四 分律 [Four-Part Vinaya] was mainly used during the mid-late period of the Northern dynasties. This basic division gradually took place during the first half of the fifth century. In the early fifth century, Shisong lü was translated in Chang'an in the north. In the subsequent twenty years, Mobe sengqi lï and Wufen lü were successively translated in Jiankang in the south. Shortly after Shisong lü was translated, Yao Qin was destroyed and the north was frequently at war and chaos. Shisong lü was not wide-spread in the north. It was Vimalākṣa who brought it to Xin Monastery in Jingzhou and spread it to the Southern dynasties from there, then finally established Shisong lü's important status in the Southern dynasties. Since Mohe sengqi lü and Wufen lü were translated in Jiankang, due to being drawn into the debate on squatting to eat and other issues and being caught in the dispute between Chinese and foreigners, their broad acceptance in the Southern dynasties was quite limited. This in turn created an opportunity for the Shisong lü in the south.

Even though the Mohe sengqi lü brought back by Faxian did not set down roots in the Southern dynasties, it should have been transmitted to Jingzhou when Faxian went to Xin Monastery in the 420s, when its Chinese translation was completed. Jingzhou was the place where north and south met. It was also a crucial place for the study of Vinaya. This provided great conditions for the outward spread of Mohe sengqi lü, especially its circulation in the northern regions. In addition, approximately twenty years after Faxian arrived in Xin Monastery, the persecution of Buddhism by Emperor Taiwu of Northern Wei broke out on a large scale in northern China. After the persecution of Buddhism, there was an urgent need among the monastics for the restoration of Vinaya. This provided a good opportunity for Mohe sengqi lü to establish its dominance during the early-mid Northern dynasties. Zhidao's 志道 biography in the Gaoseng zhuan states:

In the past, Wei Lu persecuted the Buddha Dharma, and while later generations restored its glory, there were many faults with the transmission of the precepts. Zhidao therefore made vows to propagate 
and disseminate it, not fearing difficulties or hardship. He brought together over ten people of like resolve, and went to Hulao. He gathered scholars of the way from the five prefectures of Luo, Qin, Yong, Huai and $\mathrm{Yu}$, to meet together at Yinshui Monastery, where they lectured on the Vinaya and illuminated the precepts, then explained the Dharma of receiving [the precepts]. The integrity of the monastic discipline in the illegitimate regime was due to Zhidao's efforts.

先時魏虜滅佛法, 後世嗣興, 而戒授多關. 道既誓志弘通, 不憚艱 苦，乃攜同契十有餘人，往至虎牢. 集洛、秦、雍、淮、豫五州道 士, 會於引水寺. 講律明戒, 更申受法. 偽國僧禁獲全, 道之力也..$^{58}$

After Emperor Taiwu of Northern Wei's persecution of Buddhism, in order to revive the Vinaya, Zhidao conducted the largescale event in the north where he lectured on the Vinaya and illuminated the precepts, then explained the Dharma of receiving [the precepts]' (講律明戒, 更申受法). Mohe sengqi lü finally established its position in the early-mid Northern dynasties. Composed in the early Northern Qi period, 'Shi lao zhi' 釋老志 [Treatise on Buddhism and Daoism] in Wei shu 魏書 [Book of Wei] states:

The śramana Faxian regretted that the Vinaya canon was incomplete, and travelled from Chang'an to India. Passing through over thirty countries, wherever there were sutras and Vinayas he would study the language of the texts, translate them and put them into writing. ... His Vinayas were fluently translated, but these were unable to be completely accurate. Arriving in Jiangnan, he then discussed and edited them with the Indian meditation master Buddhabhadra. This was the [Mohe] sengqi lü, which while fully completed in the past, is received and upheld by śramanas of the present day.

沙門法顯, 慨律藏不具, 自長安遊天答. 曆三十余國, 隨有經律之 處, 學其書語, 譯而寫之...... 其所得律, 通譯未能盡正. 至江南,

\footnotetext{
58 Tang, Gaoseng zhuan, 435.
} 
更與天笂禪師跋陀羅辯定之, 謂之《僧祇律》, 大備於前, 為今沙 門所持受. ${ }^{59}$

The statement that Mobe sengqi lü is received and upheld by śramanas of the present day' (為今沙門所持受) reflects the situation from Northern Wei to early Northern Qi. All in all, there was a direct relationship between Faxian's propagation of Mobe sengqi lü and its enormous impact during the early-mid period of the Northern dynasties, after it was transmitted to China.

\section{Conclusion}

Many of the arguments concerning the life of Faxian in the present paper are of a speculative nature. However, we believe that, in general, two points are certain. First, in 399 CE, Faxian set out for India and other places in South Asia in search of Vinaya. He went out shortly after receiving full ordination, which was around the age of twenty, at the prime of his life. Second, he already left for Xin Monastery in Jingzhou before translation of Wufen lü was completed in Jiankang in $423 \mathrm{CE}$.

The two points above conform to and can be linked up with various extant historical materials. Both Chu sanzang $j i$ ji and Gaoseng zhuan are based on and further elaborate the account of point one. After receiving full ordination, Faxian bemoaned that the precepts were incomplete, and therefore set out from Chang'an to seek the precepts. Even if we base our arguments on textual sources like Gaoseng zhuan and consider that Faxian already 'passed away' before $423 \mathrm{CE}$, it could still explain point two. Faxian definitely left for Xin Monastery in Jingzhou before $423 \mathrm{CE}$. Regardless of the age at which Faxian passed away, whether it was over eighty years old, or in his forties and fifties as proposed by Chen Yuan, it would only affect the length of time which Faxian was at Xin monastery in Jingzhou. (The character ' $b a$ '八 [eight] from

\footnotetext{
59 Tsukamoto, Wei shu Shi laozhi yanjiu, 105.
} 
the statement 'eighty-six years' 春秋八十有六 from Faxian's biography in the Chu sanzang ji ji could possibly be the character 'si' 四 [four] originally. Hence, the statement could be 'forty-six years' 春秋四十有六 instead. When transcribing the text, issues like the print of the outer square ' $\square$ ' of the character ' $s i$ ' 四 might be too faded to see, hence mistaken for ' $b a$ ' 八. It is also possible that this error was carried over and impacted the compilation of Gaoseng zhuan).

Three conclusions can be drawn from the above two points:

First of all, Faxian was born around the time of the 370s. During this time, the religious practice of giving novice precepts to young children to prevent premature death already emerged in northern China. Children receiving the novice precepts for this reason did not do so in order to renounce in the future. They also did not live in monasteries after receiving the novice precepts.

Secondly, Liu Yu was pronounced emperor and established the Liu Song dynasty in 420 CE. In the early 420s, when Faxian was in his forties, he left the capital of Liu Song, Jiankang, and went up north to Xin Monastery in Jingzhou. The reasons for this move were, firstly, to avoid the debate among the Buddhist circle in Jiankang on squatting to eat, which was caused by the Mobe sengqi lü, a text which he brought back and helped translate. The second reason was to fulfil his wish of returning to his homeland. Xin Monastery was appealing to Faxian, as it was the centre of the study of Vinaya at the time, especially for the propagation of Shisong lü. That was why Faxian left Jiankang, even though the translations of the Sanskrit sutras and Vinayas he brought back were not yet finished.

Lastly, when Faxian arrived in Xin Monastery in early the 420s, he encountered Shisong lü, as well as its thought and study brought to Jingzhou from Chang'an in the north by Kumārajīva's Sangha. Meanwhile, Faxian also disseminated the newly translated Mobe sengqi lü as well as its thought and study from Jiankang down south to Xin Monastery in Jingzhou. At that time, Xin Monastery in Jingzhou became a place where the thought and study of the Vinaya in the north and south converged. If Faxian passed away in his forties or fifties (in the case of his age being forty-six years old), it would mean that Faxian did not live to return north to his homeland in Chang'an. 
If Faxian passed away when he was over eighty years old, then it would mean that he decided to settle in Jingzhou and lived in Xin Monastery for a long time.

In summary, Faxian received the novice precepts at a young age. However, he did not live in the monastery afterwards. The purpose for his family's decision to have him receive the novice precepts was not for him to renounce as a monastic, but simply to prevent him from dying of illness at a young age. This particular religious practice during the Eastern Jin period is worthy of our attention. Furthermore, after receiving full ordination as an adult, Faxian bemoaned that the precepts were incomplete. He was also concerned about whether he truly received the precepts. These were the important factors that drove his desire to travel to the West in search of the Dharma and Vinaya. Therefore, Faxian must have left for India in his prime, shortly after receiving full ordination. It would have been impossible for him to wait until later in life, in his sixties, to then travel to the West along with colleagues of similar age. The basis of the current view that Faxian travelled to the West later in life is mainly based on deduction of his death year and age of death. However, there appears to be room for discussion on his age of death and the year in which he passed away at Xin Monastery, Jingzhou. Lastly, Faxian felt the urge to leave the capital, Jiankang, for Xin Monastery in Jingzhou without finishing the translation of all the scriptures he brought back. This directly connects with the situation at the time, that there was a group of monastics from the north bringing Kumārajīva's new translation of Shisong lü down south to Xin Monastery and stationing there. In addition, Faxian also brought the newly translated Mobe sengqi lü from Jiankang along with him to Jingzhou. Jingzhou was the place where the north and south converged. Faxian lived in Xin Monastery later in his life. He was an important founding force in the exchanges between precepts in the north and south, that is, the Mobe sengqi lü, popular during the early-mid period of the Northern dynasties, and Shisong lü, popular during the Southern dynasties. 


\section{Bibliography}

Abbreviations

T Taishō shinshū daizōkyō 大正新脩大蔵経. See Bibliography, Secondary Sources, Takakusu and Watanabe, eds. X Wanzi Xuzang jing 记字續藏經. See Bibliography, Secondary Sources, Wanzi Xuzang jing.

\section{Primary Sources}

Chu sanzang ji ji 出三藏記集 [Collection of the documents Related to the Translation of the Tripitaka]. 15 juan. Initially compiled by Sengyou 僧祐 (445-518) in 515. T no. 2145, vol. 55.

References made to Su Jinren 蘇晉仁 and Xiao Lianzi 蕭鍊子, et al, annotated (see Secondary Sources).

Faxian zhuan 法顯傳 [Account by Faxian], also known as Gaoseng Faxian zhuan 高僧法顯傳 [Account by the Eminent Monk Faxian]. 1 juan. By Faxian 法顯 (337-422). T no. 2085, vol. 51. References made to Zhang Xun 章巽, edited and annotated (see Bibliography 3, Modern Studies).

Gaoseng Zhuan 高僧傳 [Eminent Monk Biographies]. 14 juan.

Initially completed by Huijiao 慧饺 (497-554) sometime between 519 and 522 (final version probably completed ca. 530). T no. 2059, vol. 50. References made to Tang Yongtong 湯用㣍, annotated (see Bibliography 3, Modern Studies).

Guang Hongming ji 廣弘明集 [Extension of the Hongming Ji

(Collection of Documents Promoting Buddhism)]. 30 juan.

Compiled by Daoxuan 道宣 (596-667) in 664 and under continuous revision until at least 666. T no. 2103, vol. 52 .

Jin shu 晉書 [History of the Jin Dynasty]. 130 juan. By Fang Xuanling 房玄齡 (578-648) in 648. Beijing: Zhonghua shuju 中 華書局, 1974 .

Siku quanshu 四庫全書 [Complete Library in Four Branches of Literature]. 79,337 juan. Compiled by Ji Yun 紀昀 (17241805), et al, between 1773 and 1782. Shanghai: Shanghai guji chubanshe 上海古籍出版社, 1987. 
Song shu 宋書 [The Book of Song]. 100 juan. Initially finished in 488 by Sheng Yue 沈約 (441-513). Beijing: Zhonghua shuju, 1974.

Zizhi tongjian 資治通鑑 [Comprehensive Mirror to Aid in Government]. 294 juan. By Sima Guang 司馬光 (1019-1086?), et al., and presented to the court in 1084. Beijing: Zhonghua shuju 中華書局, 1976.

\section{Secondary Sources}

Chen Yuan 陳垣. Shishi yinian lu 釋氏疑年錄 [Record of Dubious Dates of Buddhist Monks]. Beijing: Zhonghua shuju 中華書局, 1964.

Chen Zhiyuan 陳志遠. ‘Qihuan si jushi zhizheng zaikao’祇洹寺踞食 之猙再考 [A Re-examination of the Debate on Squatting to Eat at Qihuan Monastery]. Zhongguo zhonggu shi yanjiu 中國中古史 研究 [Study of Medieval Chinese History] 5 (2015): 38-54.

Li Ping 李憑. Beiwei pingcheng shidai 北魏平城時代 [The Pingcheng Regime of the Northern Wei Period]. Shanghai: Shanghai guji chubanshe 上海古籍出版社, 2014.

Nakano Tatsue 中野達慧, et al., comps. Dai Nibon zoku zōkyō大日 本續藏經 [Extended Buddhist Canon of Great Japan], 120 cases. Kyoto: Zōkyō shoin 藏經書院, 1905-1912.

Su Jinren 蘇晉仁, Xiao Lianzi 蕭鍊子, et al., annot. Chu sanzang ji ji 出三藏記集 [Compilation of Documents on the Translation of the Tripitaka]. Beijing: Zhonghua shuju 中華書局, 1995.

Takakusu Junjirō 高楠順次郎, and Watanabe Kaigyoku 渡邊海旭, eds. Taishō shinshū daizōkyō 大正新修大藏經 [Buddhist Canon Compiled during the Taishō Era (1912-1926)]. 100 vols. Tokyo: Taishō issaikyō kankōkai 大正一切經刊行會, 1924-1932.

Tang Yongtong 湯用形, annot. Gaoseng zhuan 高僧傳 [Biographies of Eminent Monks]. Beijing: Zhonghua shuju 中華書局, 1992.

Tsukamoto Zenryu 塚本善隆. Wei shu Shi laozhi yanjiu 魏書釋老 志研究 [A Study on the Treatise on Buddhism and Daoism in the Book of Wei]. Translated by Lin Baoyao 林保堯. Hsinchu: Juefeng Fojiao yishu wenhua jijinhui 覺風佛教藝術文化基金會, 2008.

Wanzi Xuzang jing 叉字續藏經 [Man Extended Buddhist Canon]. 
150 vols. Xin wenfeng chuban gongsi 新文豐出版公司, Taibei 臺 北, 1968-1970. Reprint of Nakano, et al., comps., Dai Nibon zoku zōkyō.

Wang Su 王素, and Li Fang 李方. Wei Jin Nanbeichao Dunbuang wenxian biannian 魏晉南北朝敦煌文獻編年 [Annals of Wei, Jin, Northern and Southern Dynasties Dunhuang Manuscripts]. Edited by Jao Tsung-i 饒宗匵. Taipei: Xinwenfeng chuban gongsi 新文豐出版公司, 1997.

Yoshikawa Tadao 吉川忠夫. Liuchao jingshen shi yanjiu 六朝精神 史研究 [Studies on the Spiritual History of the Six Dynasties]. Translated by Wang Qifa 王啟發. Nanjing: Jiangsu renmin chuban she 江蘇人民出版社, 2012.

Zhang Xun 章巽, ed. and annot. Faxian zhuan jiaozhu 法顯傳校注 [Account of Faxian, Edited and Annotated]. Beijing: Zhonghua shuju 中華書局, 2008. 